\title{
UJI AKTIVITAS ANTIOKSIDAN KOMBINASI INFUSA BIJI ALPUKAT (Persea americana) DAN BIJI PEPAYA (Carica papaya L.) TERHADAP TIKUS PUTIH (Rattus norvegicus) DIABETES MELLITUS DENGAN PARAMETER MDA
}

\author{
Safriani Rahman, Rachmat Kosman, Sudrianto \\ Fakultas Farmasi Universitas Muslim Indonesia Makassar \\ Email : safriani_rahman@yahoo.com.
}

\begin{abstract}
This research aims to determine the concentration Infusa Seeds Avocado and papaya seeds effective leaves that have antioxidant activity to MDA levels in diabetic mellitus with rats was induced with alloxan. This research used 21 white rats were divided into 7 groups. All rats were induced by alloxan $110 \mathrm{mg} / \mathrm{KgBB}$ intraperitoneally. Group I as a normal control,group II was administered with Na.CMC as a negative control, group III avocado seed infusion of $10 \%$, group IV papaya seed infusion of $10 \%$, group $V$ infusion combination of avocado seeds and papaya seeds $4 \% \mathrm{v} / v$, group IV infusion combination of avocado seeds and papaya seeds $6 \% v / v$, group VII infusion combination of avocado seeds and papaya seeds $8 \% \%$. Administration were given orally for 14 days orally. Before treatment, all groups except the group I was induced with alloxan $110 \mathrm{mg} / \mathrm{kgBB}$ in intraperitonially. Measurement of MDA levels before and after administration of infusion. MDA levels as measured on a spectrophotometer $532 \mathrm{~nm}$ wavelength. MDA Assay performed with TBA method. The results showed that the combined infusion of avocado seeds and papaya seeds, concentrations of $4 \% \mathrm{v} / v, 6 \% \mathrm{v} / v, 8 \% \mathrm{v} / v$ effective as an antioxidant.
\end{abstract}

Keywords : Diabetes, antioxidants, malondialdehyde (MDA), avocado seeds and papaya seeds

\section{PENDAHULUAN}

Diabetes mellitus

(DM)

merupakan salah satu penyakit kronis yang terjadi ketika pankreas tidak dapat lagi memproduksi insulin atau insulin yang dihasilkan kurang dan tidak cukup untuk memenuhi kebutuhan insulin dalam tubuh. Penyakit diabetes mellitus biasa ditandai dengan meningkatnya kadar glukosa darah yang sering disebut hiperglikemia yang dapat menyebabkan kerusakan yang serius terhadap beberapa sistem tubuh terutama sistem saraf dan pembuluh darah. Penyakit ini merupakan salah satu penyakit yang menyebabkan peningkatan resiko kematian (Price, 2005).

Penderita diabetes mellitus yang ditandai dengan hiperglikemia ini dapat menyebabkan peningkatan stres 
Uji Aktivitas Antioksidan Kombinasi Infusa Biji Alpukat Dan Biji Pepaya Terhadap Tikus Putih Diabetes Mellitus Dengan Parameter MDA

oksidatif. Hiperglikemia akan menyebabkan terjadinya auto oksidasi glukosa sehingga terbentuk radikal bebas, glikosilasi auto-oksidatif, dan meningkatnya jalur perubahan glukosa, sorbitol, dan fruktosa yang akan menurunkan antioksidan (Wiyono, 2003).

Pada kondisi sistem antioksidan tidak normal atau kekurangan antioksidan yang ada, maka terjadi hiperproduksi Reactive Oxigen Spesies (ROS), hal ini menimbulkan stres oksidatif. Stres oksidatif merupakan salah satu komponen pada mekanisme kerusakan jaringan pada manusia, dimana dapat ditunjukkan dengan meningkatnya kadar MDA dalam serum (Siswanto, 2012).

Pengobatan diabetes mellitus telah dilakukan dengan berbagai cara, seperti olah raga dan diet. Pengobatan dapat pula dengan pemberian insulin maupun menggunakan obat-obatan antidiabetes yang dijual dipasaran atau lebih dikenal sebagai obat sintetis (BPOM, 2010). Pengobatan secara tradisional didasarkan pada faktorfaktor empiris, kebiasaan, dan pengalaman. Umumnya mekanisme pengobatan secara tradisional tidak dapat dijelaskan secara rinci seperti pengobatan sintetis (Wijayakusuma, 2004).
Biji alpukat (Persea americana) dan biji pepaya (Carica papaya) secara empiris dapat digunakan untuk menurunkan kadar glukosa darah. Biji alpukat (Persea americana) mengandung senyawa golongan polifenol, flavonoid, triterpenoid dan tanin yang dapat meningkatkan sensitivitas insulin, maka insulin dapat bekerja secara normal sehingga mencegah penyakit diabetes mellitus. Biji pepaya (Carica papaya) mengandung tanin, saponin, alkaloid, dan flavonoid. Senyawa flavanoid pada biji alpukat dan biji pepaya bermanfaat sebagai antioksidan untuk menurunkan kadar glukosa darah melalui perbaikan fungsi pankreas (dengan cara regenerasi sel) untuk meningkatkan produksi insulin (Sholhah, 2013).

\section{METODE PENELITIAN}

\section{Alat dan Bahan yang digunakan}

Alat yang digunakan pada penelitian ini yaitu batang pengaduk, belender, botol semprot, corong, gelas kimia $\left(\right.$ Pyrex $\left.^{\circledR}\right)$, gelas ukur $\left(\right.$ Pyre $\left.^{\circledR}\right)$, kain saring, kandang tikus, kanula, kuvet, labuukur, panci infusa, pipa kapiler, pipet tetes, spoit, spektrofotometri Uv-vis, seperangkat alat glukometer (Gluco $\mathrm{DR}^{\circledR}$ ), seperangkat alat sentrifugasi, tabung sentrifuge, stopwatch, timbangan 
Uji Aktivitas Antioksidan Kombinasi Infusa Biji Alpukat Dan Biji Pepaya Terhadap Tikus Putih Diabetes Mellitus Dengan Parameter MDA

analitik dan timbangan O'hauss $\left(\right.$ Camry $\left.{ }^{\circledR}\right)$.

Bahan yang digunakan pada penelitian ini yaitu aquadest, aloksan, asam klorida, asama setat glasial, biji alpukat (Persea americana), biji pepaya (Carica papaya L.), EDTA, etanol, ketamin, kertas timbang, n-butanol, $\mathrm{NaCl}, \mathrm{Na}-\mathrm{CMC}, \mathrm{Na}_{2} \mathrm{SO}_{4}$, strip test glukosa, TBA (Asam tiobarbiturat) dan TCA (Asam trikloroasetat).

\section{Prosedur Kerja}

Pembuatan Bahan Penelitian

Pembuatan infusa biji alpukat (Persea americana) dan biji pepaya (Carica papaya L.)

\section{Pembuatan infusa biji alpukat}

Sebanyak 10 gram serbuk biji alpukat ditimbang kemudian dimasukkan ke dalam panci infusa, ditambahkan aquadest $100 \mathrm{ml}$. Panaskan di atas tangas air selama 15 menit terhitung mulai suhunya mencapai $90^{\circ} \mathrm{C}$, sambil sesekali diaduk-aduk. Serkai selagi panas menggunakan kain flanel, tambahkan air panas secukupnya melalui ampas hingga diperoleh volume infusa yang dikehendaki yaitu $100 \mathrm{ml}$ (10\%).

\section{Pembuatan infusa biji papaya}

Sebanyak 10 gram serbuk biji pepaya ditimbang kemudian dimasukkan ke dalam panci infusa, ditambahkan aquadest $100 \mathrm{ml}$. Panaskan di atas tangas air selama 15 menit terhitung mulai suhunya mencapai $90^{\circ} \mathrm{C}$, sambil sesekali diaduk-aduk. Serkai selagi panas menggunakan kain flanel, tambahkan air panas secukupnya melalui ampas hingga diperoleh volume infusa yang dikehendaki yaitu $100 \mathrm{ml}$ (10\%).

\section{Pembuatan larutan aloksan}

Sebanyak $480 \mathrm{mg}$ serbuk aloksan kemudian dilarutkan dengan larutan $\mathrm{NaCl}$ fisiologis, kemudian dihomogenkan

4. Pembuatan EDTA $10 \%$

Sebanyak 10 gram EDTA ditimbang lalu dilarutkan dengan sedikit aquadest hingga homogen kemudian dicukupkan volumenya hingga $100 \mathrm{ml}$.

\section{Pembuatan Asam Asetat $\mathbf{1 0} \%$}

Sebanyak $10 \mathrm{ml}$ asam asetat dilarutkan dengan sedikit aquadest kemudian diencerkan sampai volume larutan menjadi 100 $\mathrm{ml}$.

6. Pembuatan TCA $10 \%$

Sebanyak 10 gram asam trikloroasetat ditimbang lalu dilarutkan dengan sedikit aquadest, kemudian diencerkan sampai volume larutan menjadi $100 \mathrm{ml}$. 
Uji Aktivitas Antioksidan Kombinasi Infusa Biji Alpukat Dan Biji Pepaya Terhadap Tikus Putih Diabetes Mellitus Dengan Parameter MDA

7. Pembuatan $\mathrm{Na}_{2} \mathrm{SO}_{4} 2 \mathrm{~mol} / \mathrm{L}$

Sebanyak 14,204 gram natrium sulfat ditimbang lalu dilarutkan dengan sedikit aquadest, kemudian diencerkan sampai volume larutan menjadi $50 \mathrm{ml}$.

\section{Pembuatan TBA}

Sebanyak $100 \mathrm{mg}$ asam tiobarbiturat ditimbang lalu dilarutkan dengan sedikit aquadest, kemudian diencerkan sampai volume larutan menjadi $50 \mathrm{~mL}$ $\mathrm{Na}_{2} \mathrm{SO}_{4}$.

\section{Pemilihan dan Penyiapan Hewan Uji}

Sebanyak 21 ekor tikus yang disiapkan kemudian dibagi dalam 7 kelompok tiap kelompok terdiri dari 3 hewan coba. Masing-masing kelompok diinduksi dengan aloksan selama 2×24 jam, adapun pembagian kelompoknya sebagai berikut :

a. Kelompok I normal.

b. Kelompok II (kontrol negatif) di beri Na.CMC.

c. Kelompok III diberi infusa biji alpukat $10 \%$.

d. Kelompok IV diberi infusa biji pepaya $10 \%$.

e. Kelompok $V$ diberi kombinasi infusa biji alpukat dan biji papaya $4 \% \mathrm{v} / \mathrm{v}$

f. Kelompok VI diberi kombinasi infusa biji alpukat dan biji papaya $6 \% \mathrm{v} / \mathrm{v}$ g. Kelompok VII diberi kombinasi infusa biji alpukat dan biji papaya $8 \% \mathrm{v} / \mathrm{v}$

\section{Perlakuan terhadap Hewan Uji}

Hewan uji dipuasakan selama 8 jam dan selanjutnya diukur kadar glukosa darah puasanya sebagai kadar glukosa awal ( $\left.T_{0}\right)$ selanjutnya semua hewan uji diinduksi aloksan dengan dosis $120 \mathrm{mg} / \mathrm{kgBB}$ secara intraperitonial selama $2 \times 24$ jam. Lalu dilakukan pengukuran kadar glukosa darah sebagai kadar glukosa darah induksi.

Kelompok I tidak diberi apa-apa sebagai kontrol normal, kelompok II diberi Na.CMC sebagai kontrol negatif, kelompok III diberi infusa biji alpukat $10 \%$, kelompok IV diberi infusa biji pepaya $10 \%$, kelompok $\mathrm{V}$ diberi kombinasi infusa biji alpukat dan biji pepaya $4 \% \mathrm{v} / \mathrm{v}$, kelompok $\mathrm{VI}$ diberi kombinasi infusa biji alpukat dan biji pepaya $6 \% \mathrm{v} / \mathrm{v}$, kelompok VII diberi kombinasi infusa biji alpukat dan biji pepaya $8 \% \mathrm{v} / \mathrm{v}$, semua pemberian dilakukan secara oral sebanyak 5 $\mathrm{ml} / 100 \mathrm{grBB}$. Pemberian dilakukan selama 14 hari, pengukuran kadar glukosa darah dilakukan pada hari ke1, 3, 7, 11, dan 14. Selanjutnya dilakukan pengukuran kadar glukosa darah dengan cara darah hewan uji diambil melalui ujung ekor dan 
Uji Aktivitas Antioksidan Kombinasi Infusa Biji Alpukat Dan Biji Pepaya Terhadap Tikus Putih Diabetes Mellitus Dengan Parameter MDA

diteteskan pada strip glukometer yang sebelumnya telah diaktifkan sehingga secara otomatis akan terbaca pada monitor dari glukometer tersebut. Prinsip metode ini adalah secara enzimatik melibatkan reaksi glukosa oksidase yang menghasilkan intensitas warna yang akan dideteksi oleh alat ini.

\section{Pengambilan Darah Hewan Uji}

Proses pengambilan darah pada hewan uji tikus (Rattus norvegicus) dilakukan secara plexus retroorbitalis. Tikus diinjeksi dengan ketamin 0,3 $\mathrm{mL}$ (Ketamin hidroklorida $50 \mathrm{mg} / \mathrm{mL}$ ) secara intraperitoneal, Kemudian pipa kapiler digoreskan pada medial canthus mata di bawah bola mata kearah foramen opticus. Pipa kapiler diputar sampai melukai plexus dan darah ditampung pada vial yang telah diberi EDTA.

\section{Analisis MDA}

Darah dikumpulkan dalam vial yang berisi larutan EDTA. Sebanyak 1 $\mathrm{ml}$ darah dimasukkan ke dalam tabung sentrifuge dan kemudian protein diendapkan dengan menambahkan 2,5 $\mathrm{ml}$ dari $20 \mathrm{~g} / \mathrm{mL}$ asam trikloroasetat. Setelah itu disentrifuge pada 1000 rpm selama 10 menit kemudian supernatant dipisahkan. Endapan protein disuspensikan kembali dalam 2,5 $\mathrm{ml}$ asam asetat dan ditambahkan 3 $\mathrm{ml}$ asam tiobarbiturat $(2 \mathrm{~g} / \mathrm{L}$ dalam $2 \mathrm{~mol} / \mathrm{L} \quad \mathrm{Na}_{2} \mathrm{SO}_{4}$ ). Campuran reaksi dipanaskan dalam waterbath selama 30 menit, kemudian didinginkan cepat dalam icebath untuk menghentikan reaksi, kemudian diekstraksi dengan menambahkan n-butanol sebanyak 4 $\mathrm{ml}$ dan disentrifuge kembali pada 3000 rpm selama 10 menit. Hasil sentrifuge tersebut diukur absorbansinya pada spektrofotometri dengan panjang gelombang $532 \mathrm{~nm}$.

\section{Analisis Data}

Data penelitian yang diperoleh, dikumpulkan dan kemudian diolah dan dianalisis secara statistik berdasarkan analisis uji $t$-berpasangan (untuk melihat perbedaan kadar MDA antara data sebelum dan setelah perlakuan), Uji anova-satu arah (untuk melihat apakah penurunan pada kadar MDA antara kelompok perlakuan sama atau tidak), dan Uji post hoc LSD (untuk melihat perbedaan penurunan kadar MDA antara masing-masing kelompok perlakuan). 
Uji Aktivitas Antioksidan Kombinasi Infusa Biji Alpukat Dan Biji Pepaya Terhadap Tikus Putih Diabetes Mellitus Dengan Parameter MDA

HASIL PENELITIAN

Tabel 1. Rata-rata kadar MDA awal, MDA setelah induksi dan MDA setelah terapi infusa pada tikus (Rattus norvegicus) diabetes mellitus

\begin{tabular}{|c|c|c|c|c|c|}
\hline \multirow{2}{*}{ Perlakuan } & \multicolumn{3}{|c|}{ Absorbansi MDA (Malondialdehid) \pm SD } & \multirow{2}{*}{$\begin{array}{c}\% \\
\text { Penurunan }\end{array}$} & \multirow{2}{*}{$P(95 \%)$} \\
\hline & Awal & Induksi & Terapi & & \\
\hline Normal & $0.056 \pm 0.019$ & $0.053 \pm 0.011$ & $0.027 \pm 0.003$ & 48.49 & \\
\hline Na.CMC & $0.056 \pm 0.010$ & $0.214 \pm 0.028$ & $0.570 \pm 0.391$ & -183.81 & \\
\hline Infusa biji alpukat $10 \%$ & $0.059 \pm 0.037$ & $0.139 \pm 0.035$ & $0.034 \pm 0.029$ & 77.58 & \\
\hline Infusa biji pepaya $10 \%$ & $0.045 \pm 0.027$ & $0.127 \pm 0.020$ & $0.058 \pm 0.039$ & 52.11 & 0.016 \\
\hline Kombinasi $4 \% \mathrm{v} / \mathrm{v}$ & $0.022 \pm 0.007$ & $0.125 \pm 0.024$ & $0.076 \pm 0.064$ & 33.13 & \\
\hline Kombinasi $6 \% \mathrm{v} / \mathrm{v}$ & $0.064 \pm 0.016$ & $0.112 \pm 0.006$ & $0.013 \pm 0.007$ & 88.57 & \\
\hline Kombinasi $8 \% \mathrm{v} / \mathrm{v}$ & $0.057 \pm 0.035$ & $0.156 \pm 0.008$ & $0.035 \pm 0.008$ & 76.99 & \\
\hline
\end{tabular}

\section{PEMBAHASAN}

Pengujian aktivitas antioksidan infusa biji alpukat (Persea americana) dan biji pepaya (Carica papaya L.) dengan parameter MDA dilakukan dengan metode Thiobarbiturat Acid (TBA). Metode ini merupakan metode yang paling banyak dan paling sering digunakan untuk mengukur keberadaan radikal bebas, mudah dikerjakan, mempunyai kepekaan yang cukup tinggi, mudah diaplikasikan untuk berbagai sampel. Metode ini didasarkan pada pembentukan reaksi antara 1 molekul MDA dengan 2 molekul TBA (Thiobarbiturat Acid) yang menghasilkan warna merah yang dapat menyerap cahaya pada panjang gelombang $532 \mathrm{~nm}$. Semakin pekat warna yang dihasilkan maka konsentrasi MDA juga semakin tinggi. Jumlah MDA yang terbentuk menggambarkan proses peroksidasi lipid. Dimana semakin tinggi absorbansi MDA semakin besar aktivitas radikal bebas, sebaliknya semakin rendah absorbansi MDA semakin kecil aktivitas radikal bebas.

Penelitian ini menggunakan tikus (Rattus norvegicus) dikarenakan genetik, karakteristik biologi dan perilakunya sangat mirip manusia dan banyak gejala kondisi manusia dapat direplikasi pada tikus. Tikus betina tidak digunakan dalam penelitian ini, karena sistem hormonalnya tidak stabil dibandingkan dengan tikus jantan sehingga dapat mempengaruhi hasil penelitian.

Sebelum perlakuan, tikus dipuasakan 8 jam untuk meminimalkan faktor pengaruh makanan pada pengukuran kadar glukosa darah, kemudian diinduksi dengan aloksan $110 \mathrm{mg} / \mathrm{kgBB}$ secara intraperitonial. Aloksan akan merusak sel-sel 
Uji Aktivitas Antioksidan Kombinasi Infusa Biji Alpukat Dan Biji Pepaya Terhadap Tikus Putih Diabetes Mellitus Dengan Parameter MDA

penghasil insulin yaitu sel $\beta$ - pulau langerhans dengan cara reduksi aloksan menjadi asam dialurat yang kemudian mengalami reoksidasi menjadi aloksan sehingga menghasilkan radikal ion superoksida yang kemudian terbentuk radikal bebas hidrogen peroksida yang dapat menyerang komponen penyusun sel sehingga menyebabkan kerusakan sel pada sel $\beta$ - pulau langerhans.

Hasil pengujian aktivitas antioksidan infusa biji alpukat 10\%, infusa biji pepaya $10 \%$, kombinasi infusa biji alpukat dan biji pepaya $4 \% \mathrm{v} / v$, kombinasi infusa biji alpukat dan biji pepaya $6 \% \% / v$, dan kombinasi infusa biji alpukat dan biji pepaya $8 \% \mathrm{v} / v$ (dapat dilihat pada tabel 1), pada tabel 1 menunjukkan bahwa pada setiap kelompok perlakuan mengalami peningkatan kadar MDA setelah induksi, dan terjadi penurunan kadar MDA setelah pemberian terapi infusa selama 14 hari kecuali kelompok Na.CMC. Dari tabel 1 tersebut kemudian dibuat dalam sebuah grafik (dapat dilihat pada gambar 1). Pada gambar 1 menunjukkan bahwa kelompok perlakuan normal mengalami penurunan kadar MDA setelah terapi meskipun tidak diberikan infusa biji alpukat dan biji pepaya, itu terjadi karena sistem imun pada hewan coba bagus, dan bisa juga dipengaruhi oleh makanan dan minuman yang diberikan pada tikus. Kelompok perlakuan yang diberikan Na.CMC mengalami kenaikan kadar MDA setelah pemberian terapi infusa. Hal ini terjadi karena Na.CMC tidak mengandung komponen antioksidan yang dapat menurunkan kadar MDA dan Na.CMC tidak memiliki efek terhadap tikus sehingga tikus pada kelompok ini terus menerus terpapar oleh radikal bebas yang menyebabkan terjadinya peningkatan MDA. Kelompok infusa biji alpukat 10\% dan kelompok infusa biji pepaya $10 \%$ menunjukan peningkatan kadar MDA setelah induksi dan mengalami penurunan setelah pemberian terapi infusa selama 14 hari. Kelompok kombinasi biji alpukat dan biji pepaya $4 \% \mathrm{v} / v$, kombinasi biji alpukat dan biji pepaya $6 \% \mathrm{v} / \mathrm{v}$, dan kelompok biji alpukat dan biji pepaya $8 \% \mathrm{v} / \mathrm{v}$ (dapat dilihat pada gambar 1) menunjukan bahwa terjadi peningkatan kadar MDA setelah induksi dan penurunan kadar MDA setelah pemberian terapi infusa selama 14 hari. Kelompok kombinasi biji alpukat dan biji pepaya $6 \% \mathrm{v} / \mathrm{v}$ (dapat dilihat pada tabel 1) menunjukan penurunan kadar MDA yang paling besar dibandingkan dengan kelompok lain berdasarkan 
Uji Aktivitas Antioksidan Kombinasi Infusa Biji Alpukat Dan Biji Pepaya Terhadap Tikus Putih Diabetes Mellitus Dengan Parameter MDA

rata-rata persen penurunan kadar MDA.

Rata-rata pengukuran kadar MDA pada tabel 1 kemudian dianalisis menggunakan uji $t$-berpasangan. Untuk melihat pengaruh pemberian aloksan terhadap hewan coba, maka dilakukan analisis antara data sebelum dan sesudah induksi. Data dianalisis menggunakan metode $t$-berpasangan dari analisis tersebut didapatkan hasil bahwa data sebelum induksi $0.05221 \pm$ 0.05081 dan data setelah induksi $0.13167 \pm 0.09456$, menunjukkan nilai yang berbeda nyata yaitu $\mathrm{P}(95 \%)$ $0.000(p<0.05)$, Hal ini berarti aloksan berhasil meningkatkan kadar MDA tikus sebelum diterapi.

Penurunan kadar MDA pada kelompok kombinasi infusa biji alpukat (Persea americana) dan biji pepaya (Carica papaya) dengan konsentrasi $6 \% \mathrm{v} / \mathrm{v}$ diduga bahwa adanya penghambatan pada proses peroksidasi lipid sehingga MDA yang terbentuk berkurang. Efek penurunan ini diduga karena senyawa flavanoid dan alkaloid yang terkandung pada biji alpukat (Persea americana) dan biji pepaya (Carica papaya) memiliki efek antioksidan.

Berdasarkan hal tersebut, dapat disimpulkan bahwa kelompok kombinasi infusa biji alpukat (Persea americana) dan biji pepaya (Carica papaya) $6 \% \mathrm{v} / \mathrm{v}$ berpotensi sebagai antioksidan yang dapat menurunkan kadar MDA tikus (Rattus norvegicus) diabetes yang diinduksi aloksan dilihat dari rata-rata persen penurunan kadar MDA.

\section{KESIMPULAN}

1. Kombinasi infusa biji alpukat (Persea americana) dan biji papaya (Carica papaya) dengan konsentrasi $4 \% \mathrm{v} / \mathrm{v}, \quad 6 \% \mathrm{v} / \mathrm{v}, \quad 8 \% \mathrm{v} / \mathrm{v}$ memiliki efek antioksidan dengan menurunkan kadar MDA tikus (Rattus norvegicus) diabetes melitus yang diinduksi aloksan..

2. Kombinasi infusa biji alpukat dan biji pepaya dengan konsentrasi $6 \%$ paling efektif dalam menurunkan kadar MDA tikus putih (Rattus norvegicus) diabetes melitus yang diinduksi aloksan.

\section{DAFTAR PUSTAKA}

Price, Sylvia \& Wilson, Loraine $M$. 2005.Patofisiologi :konsepklinis proses-proses penyakit(Brahm U. Pendit.et al.,penerjemah). Jakarta : EGC,1259-1273

Sholhah FA, Tjandrakirana, Qomariyah N, 2013. Pengaruh Pemberian Kombinasi Rebusan Biji Alpukat (Persea americana) dan Biji Pepaya (Carica papaya) terhadap Kadar Glukosa Darah Mencit. Jurnal MIPA Universitas Negeri Surabaya 2(3)1: 191-193 
Uji Aktivitas Antioksidan Kombinasi Infusa Biji Alpukat Dan Biji Pepaya Terhadap Tikus Putih Diabetes Mellitus Dengan Parameter MDA

Siswanto, W. P . 2012. Pemberian Suspensi Bubuk Kedelai Dapat Menurunkan Kadar Malondialdehid (MDA) Serum pada Tikus Putih Diabetes Melitus yang Diinduksi Streptozotocin.Gaster Vol. 9 5561.
Wijayakusuma H. 2004. Atasi Diabetes Mellitus denganTanamanObat. Jakarta: PuspaSehat.

Wiyono,P. 2003. Peranan Hiperglikemia Terhadap Terjadinya Komplikasi Kronik Diabetes Melitus. Berkala IImu Kedokteran, 35, 1. 